\title{
Nasal Cavity and Paranasal Sinus Cancer TNM Finding v7
}

National Cancer Institute

\section{Source}

National Cancer Institute. Nasal Cavity and Paranasal Sinus Cancer TNM Finding v7. NCI

Thesaurus. Code C89092.

A finding about one or more characteristics of nasal cavity and paranasal sinus cancer, following the rules of the TNM AJCC v7 classification system. Nonepithelial tumors such as those of lymphoid tissue, soft tissue, bone, and cartilage are not included in this classification. (from AJCC 7th Ed.) 